\title{
Secularización, imaginario de progreso y construcción identitaria: una mirada desde el Sexenio Democrático español y las repúblicas latinoamericanas
}

\section{Secularization, imaginary progress and identity construction: a Spanish Sexenio Democrático and the Latin American republics perspective}

\author{
ALICIA MIRA ABAD \\ Universidad de Alicante, Campus de Sant Vicent del Raspeig, Ap. Correos 99- E -03080 \\ Alicante \\ alicia.mira@ua.es \\ ORCID: 0000-0003-0009-4791 \\ Recibido/Aceptado: 5-07-2017/15-11-2017 \\ Cómo citar: MIRA ABAD, Alicia, "Secularización, imaginario de progreso y construcción \\ identitaria: una mirada desde el Sexenio Democrático español y las repúblicas \\ latinoamericanas”, en Investigaciones Históricas, época moderna y contemporánea, 37 \\ (2017), pp. 204-236.
}

DOI: https://doi.org/10.24197/ihemc.37.2017.204-236

Resumen: Este trabajo es una aproximación a los usos del concepto de secularización en el mundo hispánico, desde una perspectiva comparada. Es un concepto ligado al progreso y la modernidad durante el siglo XIX, desde la premisa de que todo sistema conceptual posee un origen práctico cuando es analizado en conexión con realidades sociales y políticas diversas. El imaginario revolucionario y de modernidad lo incorporaron en la construcción de los relatos nacionales en España y América. La utilizaron como símbolo del cambio que puede conciliar pasado y futuro a través de nuevos referentes religiosos. El Sexenio Democrático y la consolidación del liberalismo en Latinoamérica nos ofrecen perspectivas y matices diversos en la utilización del concepto en espacios que comparten una misma raíz cultural.

Palabras clave: Secularización; progreso; modernidad; Sexenio Democrático; Latinoamérica.

Abstract This work is an approximation to the uses of the concept of secularization in the Hispanic world, from a comparative perspective. It is a concept linked to progress and modernity during the nineteenth century, from the premise that every conceptual system has a practical origin when is analyzed in connection with diverse social and political realities. The revolutionary imaginary and of modernity incorporated the secularization to the construction of national narratives in Spain and America. They used it as a symbol of change that can reconcile past and future through new religious referents. The Sexenio Democrático and the consolidation of liberalism in Latin America offer us different perspectives and nuances of the use of the concept in spaces that share the same cultural root.

Keywords: Secularization; progress; modernity; Sexenio Democrático; Latin America.

Sumario: Introducción. Una propuesta de estudio: el concepto, el espacio, el tiempo. 1. La secularización en la narrativa de cambio. 2. ¿Secularización frente a catolicismo como esencia nacional? 3. Los padres de la patria y "las palabras de colores". Conclusiones. Bibliografía. 


\section{INTRODUCCIÓN. UNA PROPUESTA DE ESTUDIO: EL CONCEPTO, EL ESPACIO, EL TIEMPO}

Este trabajo es una aproximación a los usos del concepto de secularización y sus interpretaciones en el mundo hispánico, ligadas en el siglo XIX a la idea de progreso y desde la premisa de que todo sistema conceptual posee un origen práctico cuando es analizado en conexión con realidades sociales y políticas diversas. El imaginario revolucionario y de modernidad lo incorporaron a los relatos nacionales en construcción. Un análisis de la retórica de progreso y modernización, con la secularización como síntoma del cambio social, en la España del Sexenio Democrático y durante la consolidación del liberalismo latinoamericano, nos permite descubrir matices diversos en la utilización del concepto en espacios que comparten una misma raíz cultural.

¿Por qué la secularización para aproximarnos a la construcción de identidades nacionales? Progreso y modernidad son inherentes al impulso revolucionario decimonónico como máxima expresión de la voluntad nacional para quebrar la vigencia de los viejos poderes. El médico y filósofo mexicano Gabino Barreda lo describe como una unión indisoluble entre la "emancipación científica, emancipación religiosa, emancipación política" constitutivas del "triple venero de ese poderoso torrente que ha ido creciendo día a día” ${ }^{1}$. La secularización forma parte de la representación del cambio y de la construcción de identidades nacionales que buscan sustentarse en nuevos principios, aunque ni en España ni en América desapareció la influencia social de la Iglesia o de los referentes religiosos.

Abordamos una época en la que no existe una relación unívoca entre ideología y vocabulario. En la España septembrina los discursos del momento evidencian la "confusión reinante", de manera que hasta los neocatólicos y carlistas podían utilizar los términos "progreso" o "liberal”. Igualmente en Latinoamérica el ejemplo de un diario católico argentino presentaba a los curas rurales como adalides del progreso moral que debían

Este trabajo se ha realizado en el marco del Proyecto de Investigación "Las monarquías en la Europa meridional (siglos XIX y XX). Culturas y prácticas de la realeza” (HAR201675954-P), financiado el Ministerio de Economía y Competitividad del Gobierno de España y con fondos FEDER de la Unión Europea.

${ }^{1}$ BARREDA, Gabino, Oración cívica. Pronunciada en la Plaza de Guanajuato el 16 de septiembre del presente año, por el ciudadano Gabino Barreda, y la poesía dicha en la misma por el ciudadano Ramón Valle. Guanajuato, 1867, Hermanos Hernández, calle de Alonso letra Y. Edición facsimilar, Universidad de Guanajuato, 1981, p. 3. 
contribuir al progreso material y a la construcción de iglesias como un símbolo del engrandecimiento de los pueblos ${ }^{2}$. Además hay que tener en cuenta la diferencia entre "discursos polémicos”, llenos de negaciones y de incitaciones a la acción y "discursos didácticos”, con un vocabulario vinculado al progreso ${ }^{3}$. En los momentos de mayor tensión político-social tuvieron mayor peso los primeros, aunque solía combinarse con los segundos, cuando se buscaba identificar los males del pasado en una retórica de ruptura que proyecta toda acción política y social hacia el futuro.

El ideal secularizador encarnaba la imagen de progreso y a la vez ayudaba a superar las abstracciones políticas en torno a la representatividad o ciudadanía derivadas de la revolución. Además podía hacerlo de forma visible y rápida a través de estrategias diversas: manifestaciones anticlericales, educación, libertad de cultos, registro civil de nacimientos, matrimonios y defunciones, las fiestas y rituales civiles, y también con un entramado discursivo que incorporaba la modernidad como hecho trascendente. Otra cosa era la interiorización del concepto como síntoma de transformación profunda. En este sentido la intensidad podía abarcar desde lo puramente epidérmico hasta la reflexión en torno al significado de laicidad y sus implicaciones en el funcionamiento del Estado y la sociedad ${ }^{4}$.

El encuadre nacional permite calibrar la fuerza del discurso secularizador como instrumento de cohesión en la construcción de la nación. En este trabajo la superación de esa perspectiva no pretende adentrarse en el campo de la historia comparada y mucho menos intenta responder a un imperativo tan alto como el enfoque transnacional ${ }^{5}$, que nos llevaría a analizar transferencias culturales entre España y América. El objetivo al plantear un marco de análisis tan amplio constreñido a la escasa extensión de un artículo es mucho más modesto. Se trata de aproximarnos a cómo se incorpora la secularización en los discursos nacionalizadores y con qué fin. El estudio de dinámicas sociopolíticas concretas combinadas con narrativas

2 “La misión del clero” en La América del Sud, 8 de marzo de 1876, citado por LIDA, Miranda, en “Algo más que un diario católico. La América del Sud (1876-1880)”, en GARABEDIAN, Marcelo H., SZIR, Sandra y LIDA, Miranda, Prensa Argentina siglo XIX. Imágenes, textos y contextos, Buenos Aires, Teseo, 2009, p. 108.

${ }^{3}$ BATTANER ARIAS, María Paz, Vocabulario político-social en España (1868-1873), Madrid, Boletín de la Real Academia Española, 1977, pp. 35-37.

${ }^{4}$ BAUBEROT, Jean, "L’invention de la laïcité », en Societé des Études Romantiques et Dix-neuviémistes, Musée d'Orsay, L'invention du XIXe siècle. Le XIXe siècle par lu-même, París, Presses de la Sorbonne Nouvelle-Klincksieck, 1999, pp. 258-70.

${ }^{5}$ PEYROU, Florencia y MARTYKÁNOVÁ, Darina, “Historia transnacional”, en Ayer, 94 (2014), pp. 18-19. 
modernizadoras predefinidas, no fundamentadas en hechos objetivos, ofrece a mi juicio un enfoque sugerente porque en esos discursos los términos se diluyen, adquieren nuevos significados o se invierten respecto a un supuesto significado original.

Paradójicamente, la ambigüedad presente en los relatos de progreso buscaba la homogeneidad nacional. En el caso americano, fue impulsada por los llamados "nation-builders", hombres de letras, del pensamiento y de la política que trataban de definir una especificidad hispanoamericana, primero respecto a un tronco español común y posteriormente en relación a los propios vecinos ${ }^{6}$, sin superar, en muchas ocasiones, el plano de lo puramente retórico o gestual. Estos individuos no pretendían apelar a un registro argumental sólido para obtener una respuesta activa. El pueblo era mero receptor de opiniones, valores, pautas de comportamiento que ellos proyectaban desde su posición pública para promover los procesos de construcción hegemónica ${ }^{7}$. También la regeneración nacional presente en los discursos del Sexenio español estuvo sustentada por prohombres del mundo político y cultural. La idea de progreso amalgamó las aspiraciones de cambio de una amplia y heterogénea coalición liberal. La composición narrativa resultante, - una identidad nacional históricamente subyugada a “obstáculos insuperables y tradicionales" y liberada por la revolución-, presentó cierta homogeneidad en los primeros momentos de una revolución que había empezado a construirse desde las filas del progresismo antes de $1868^{8}$. Sin embargo, rápidamente comenzó a deshilarse, incluso en el seno del propio republicanismo.

El Sexenio Democrático es un momento idóneo para estudiar la secularización como proceso inherente a la revolución y a "la ley del progreso universal”. Especialmente desde la óptica de los republicanos, "verdaderos autores y actores de la revolución de Septiembre, peleando

\footnotetext{
${ }^{6}$ QUIJADA, Mónica, “¿Qué nación? Dinámicas y dicotomías de la nación en el imaginario hispanoamericano”, en ANNINO, Antonio y GUERRA, François-Xavier (coords.), Inventando la nación. Iberoamérica. Siglo XIX, México, Fondo de cultura económica, 2003, p. 288.

${ }^{7}$ BONAUDO, Marta, "De la opinión publicada a la opinión pública. La prensa como lugar de representación”, BONAUDO, Marta, Imaginarios y prácticas de un orden burgués. Rosario, 1850-1930. Los actores entre las palabras y las cosas, Rosario, Prohistoria, 2005, pp. 71-96.

${ }^{8}$ VILCHES, Jorge, Progreso y Libertad. El partido progresista en la Revolución liberal española, Madrid, Alianza, 2001, p. 58; DE LA FUENTE MONGE, Jorge y SERRANO GARCÍA, Rafael, La revolución Gloriosa. Un ensayo de regeneración nacional (18681874). Antología de textos, Madrid, Biblioteca Nueva, 2005, p. 9.
} 
unidos, algunas veces con la tropa y otras muchas solos"9 . Pero no existe un proceso paralelo en el tiempo en Hispanoamérica, puesto que las repúblicas ya habían adquirido la "modernidad política" desde hacía tiempo. Puede hablarse de "condición pionera de los comportamientos hispanoamericanos en el conjunto del ámbito occidental" a la que se suma su "extraordinaria multietnicidad", de manera que a la altura de 1868 Latinoamérica se enfrentaba en materia de construcción identitaria a problemas políticos y sociales distintos a los españoles. Quijada distingue varias etapas en la consolidación de los estados iberoamericanos: desde "la nación cívica", definida por el ideal universalista y voluntarista de inclusión a través de nuevas instituciones, a la "nación homogénea", que valora la especificidad nacional frente a lo universal ${ }^{10}$. De esta evolución fueron conscientes coetáneos como Barreda para quien "después de haberse conseguido el que parecía fin único de ese fuego de renovación que cundió por todas partes” tras la independencia, emergió la idea de una especie de revolución permanente: un "incendio (que) ha consumido todavía dos generaciones enteras y aún humea después de 57 años" ${ }^{\text {"11 }}$. Por su parte, el pensador cubano José Martí atribuyó esa permanencia al propio origen de la independencia que no debería haberse circunscrito a un simple "cambio de formas, sino al cambio de espíritu" ${ }^{12}$. Es importante tener en cuenta que en las últimas décadas del XIX se produjo un viraje en la retórica nacional de progreso. El objetivo era exaltar las virtudes americanas ante la mirada peyorativa de Europa respecto a un arquetipo del latinoamericano como inferior. Los nuevos fundamentos del espíritu nacional bascularon entonces hacia el orgullo republicano y la idea de país con instituciones modernas, republicanas y progresistas frente a una Europa monárquica ${ }^{13}$. La

9 RODRIGUEZ-SOLÍS, Enrique, Historia del Partido Republicano español (De sus propagandistas, de sus tribunos, de sus héroes y de sus mártires), T. II, Madrid, Imprenta de Fernando Cao y Domingo de Val, 1893, p. 577.

${ }^{10}$ QUIJADA, Mónica, “¿Qué nación? Dinámicas y dicotomías de la nación...” pp. 307-315; QUIJADA, Mónica, BERNAND, Carmen y SCHNEIDER, Arnd, Homogeneidad y nación con un estudio de caso: Argentina, siglos XIX y XX, Madrid, CSIC, Colección tierra nueva e cielo nuevo, 42, 2000, pp. 36-38; Vid. también LOMNÉ, Georges, "El “espejo roto” de la Colombia Bolivariana”, en ANNINO VON DUSEK, Antonio, y GUERRA, FrançoisXavier (coords.), Inventando la nación..., p. 485.

${ }^{11}$ BARREDA, Gabino, Oración cívica..., p. 1.

${ }^{12}$ MARTÍ, José, La Revista Ilustrada de Nueva York, 10 de enero de 1891.

13 MARTÍNEZ, Frédéric, El nacionalismo cosmopolita. La referencia europea en la construcción nacional en Colombia, 1845-1900, Bogotá, Banco de la República, Instituto Francés de Estudios Andinos, 2001, pp. 250-251. 
reivindicación de lo propio queda patente en esta frase de Martí: "Injértense en nuestras Repúblicas el mundo; pero el tronco ha de ser el de nuestras Repúblicas $^{14}$. También en España los textos parten de un ideal revolucionario permanente y regenerador. Castelar habla de una "revolución que yo no llamo de septiembre, porque para mí no lo es ni de septiembre, ni de enero, ni de agosto, sino el grande y segundo movimiento que ha hecho la nación española, ansiosa de romper toda la continuidad con el pasado"15. Para el republicano Pi y Margall encarna "la idea de la justicia en la última de sus evoluciones conocidas" 16 .

En un espacio cultural tan amplio lógicamente se producen “disimetrías” entre estados confesionales y otros cuyo régimen republicano y laico se presenta como garantía de su independencia frente a las potencias extranjeras"17. En todos ellos la "resemantización” que experimentan los conceptos ligados al progreso nos permite distinguir matices en torno a la idea de ruptura y regeneración. Pérez Ledesma señala que la vocación generalista de los conceptos no puede hacernos olvidar sus desplazamientos, variaciones, búsqueda de complementarios y hasta movimientos opuestos respecto a la trayectoria original que los anima ${ }^{18}$. Así pues desde la simultaneidad ficticia de un mundo cultural hispánico, la modernidad se proyecta como idea-fuerza: compacta en su formulación pero sumamente heterogénea en su trayectoria. En este sentido la separación de las "palabras" y las “cosas" que señala Foucault es solo transitoria puesto que no podemos entender las variaciones en las narrativas nacionales sin tener en cuenta los contextos socio-históricos subyacentes. Sin embargo sí es posible afirmar que el ideal de modernidad decimonónico y todos sus contenidos revolución, valores republicanos, progreso o secularización- configuran una especie de límite exterior del lenguaje ${ }^{19}$, que puede ensanchar su espacio

\footnotetext{
${ }^{14}$ MARTÍ, José, La Revista Ilustrada de Nueva York, 10 de enero de 1891.

${ }^{15}$ BATTANER ARIAS, María Paz, Vocabulario político-social..., p. 84.

${ }^{16}$ PI Y MARGALL, Francisco, La reacción y la revolución. Estudios políticos y sociales T. I, Madrid, Imp. De M. Rivadeneyra, 1854, p. 200.

${ }^{17}$ DE HOYOS PUENTE, Jorge, "Catolicismo, laicismo y nación de las Españas en México: Gachupines frente a refugiados”, en SUÁREZ CORTINA, Manuel, TREJO ESTRADA, Evelina y CANO ANDALUZ, Aurora (eds.), Cuestión religiosa. España y México en la época liberal, Santander, Universidad de Cantabria, 2013, p. 397.

18 PÉREZ LEDESMA, Manuel, “Introducción” en Manuel Pérez LEDESMA (ed.): Lenguajes de modernidad en la Península Ibérica, Madrid, UAM, 2012, pp. 15-17.

19 FOUCAULT, Michel, Las palabras y las cosas. Una arqueología de las ciencias humanas, Madrid, Siglo XXI, 1968, pp. 125, 133 y 146.
} 
semántico si asume nuevos elementos que a priori no encajarían en un relato identitario derivado de la revolución.

En América Latina el inevitable enlace entre independencia y modernización para superar el pasado colonial podría haber impulsado un discurso secularizador que materializara la ruptura y un futuro construido en torno a la voluntad ciudadana. Sin embargo, las nuevas repúblicas no renunciaron totalmente a la herencia que representaba la Iglesia Católica como factor de estabilidad social. Las independencias no desembocaron directamente en Estados laicos. A lo largo del siglo XIX la asunción del ideal de progreso obligó a replantear las relaciones Iglesia y Estado en discursos más o menos radicales que evidencian la dificultad para articular una alternativa político-social homogénea ${ }^{20}$. En este proceso el 48 francés tuvo gran "resonancia", como una especie de "aprobación de la civilización a la República” o más bien la "aprobación divina a la insurrección frente a la injusticia"21, muy similar a lo ocurrido en la España septembrina cuya revolución también busca sus orígenes en las transformaciones jurídicoconstitucionales de principios de siglo $^{22}$. En esa coyuntura los liberales españoles quisieron contar con el apoyo del catolicismo, constitucionalmente declarado desde 1812 la religión de la nación, reconociéndolo así como referente de identidad colectiva y como garantía de unidad en el cambio ${ }^{23}$. Al igual que las nuevas repúblicas americanas, España tenía ante sí una tarea fundacional que suponía la construcción de una nueva legitimidad que combinara la idea de ruptura y tradición. En el imaginario de progreso desarrollado a partir de entonces se concibió la Constitución de 1812 como un "punto de partida” y la de 1869 "el término del viaje”24. En este esquema la secularización conseguía hacer perceptible una posición de no retorno a partir de la cual solo era posible avanzar hacia delante. Incluso después del Sexenio, con la llamada "Constitución interna”

${ }^{20}$ CORTÉS HERNÁNDEZ, Valeria, "Liberalismo y política en el siglo XIX. Una mirada desde México en los casos español y mexicano”, en SUÁREZ CORTINA, Manuel, Cuestión religiosa. España y México en la época liberal (ed.), Santander, Universidad de Cantabria, 2013, p. 144.

${ }^{21}$ MARTÍNEZ, Frédéric, El nacionalismo cosmopolita..., pp. 71-75.

${ }^{22}$ ANNINO VON DUSEK, Antonio, “Acerca de lo Imperial en perspectiva comparada”, en SEMATA. Ciencias Sociaes e Humanidades, 23 (2011), p. 49.

${ }^{23}$ PÉREZ GARZÓN, Juan Sisinio, "Memoria, historia y poder. la construcción de la identidad nacional española”, en COLÓM GONZÁLEZ, Francisco (ed.), Relatos de Nación. La construcción de las identidades nacionales en el mundo hispánico, Madrid-Frankfurt, Iberoamericana-Vervuert, 2005, pp. 14-15.

${ }^{24}$ El Eco de Alicante, 8 de junio de 1869. 
del conservador Cánovas, los avances secularizadores, fueron matizados pero no cuestionados porque formaban parte de ese imaginario de modernidad. La idea de una "constitución material, no escrita, formada en el devenir de los tiempos e integrada por aquellos elementos e instituciones que la historia española había consolidado hasta petrificar” podía convivir con una constitución formal y escrita, que integrara los avances del progreso siempre que la monarquía y la confesionalidad estatal se mantuvieran como elementos inmutables ${ }^{25}$. Aunque el catolicismo formaba parte del ser nacional podía ajustarse al devenir histórico sin necesidad de "revocar el edicto de Nantes"26.

La idea de un nuevo comienzo, de una vitalidad transformadora y la percepción de que todo estaba todavía por construir adquiere especial relevancia en Latinoamérica. En este sentido el trabajo de Marienstras puede ofrecernos pautas interpretativas sobre las paradojas inherentes a la construcción identitaria americana que oscila entre el voluntarismo universalista, propio de una creación artificial, hasta la nación orgánica; entre la integración de todas las etnias y su exclusión; desde la mirada hacia Europa, como origen de la civilización, a la visión de un continente caduco y corrupto $^{27}$. En España, como hemos señalado, la idea de origen derivaría del propio proceso revolucionario septembrino como continuación de las Cortes de Cádiz e incluso del inicio de los procesos de independencia americanos, considerados por el republicanismo como la lógica reacción "de todo hijo" que "al llegar a la mayoría de edad, conquista su independencia y constituye otra nueva familia" 28 .

\section{LA SECULARIZACIÓN EN LA NARRATIVA DE CAMBIO}

Si se piensa la nación como "un objeto en construcción” 29 que puede apropiarse de fragmentos de la legitimidad tradicional sin negar el ideal

\footnotetext{
${ }^{25}$ FERNÁNDEZ SARASOLA, Ignacio, Los partidos políticos en el pensamiento español. De la ilustración a nuestros días, Madrid, Marcial Pons, 2009, p. 175.

26 DARDÉ, Carlos, “Cánovas y el nacionalismo liberal español”, en CORTAZAR, Guillermo (ed.), Nación y Estado en la España liberal, Madrid, Noesis, 1994, pp. 226-27.

${ }^{27}$ MARIENSTRAS, Élise, Les mythes fondateurs de la nation américaine. Essai sur le discours idéologique aux Etats-Unis à l'époque de l'independance 1763-1800, Paris, Maspero, 1976, pp. 18-45.

${ }^{28}$ RODRIGUEZ-SOLÍS, Enrique, Historia del Partido Republicano español..., p. 122,

${ }^{29}$ PRO RUIZ, Juan, "Estado y modernidad en el lenguaje de los afrancesados”, en PÉREZ LEDESMA, Manuel (ed.): Lenguajes de modernidad en la Península Ibérica, p. 45.
} 
modernizador ¿podemos identificar un límite que convertiría a la secularización, como parte de fundamental de ese ideal, en mero revoco de la fachada nacional posrevolucionaria? Desde el momento en que el paradigma de cambio entra en contacto con la sociedad sobre el que se proyecta deberían desaparecer las ataduras clasificatorias y apriorísticas. La cuestión no reside en qué trazos del concepto se cumplen o no, sino si fue asumido como mera estrategia retórica o con plena conciencia de estar abordando "una nueva era" 30 . Evidentemente no estamos ante una construcción estática: bajo la retórica universalista y de búsqueda de libertad subyace un proyecto lleno de matices. Como señala Marienstras no es que todos los discursos identitarios de progreso tengan a priori la intención de “engañar", más bien se trata de que los problemas diagnosticados o lo puntos de ruptura detectados no encuentran un compromiso político coherente para superarlos. El discurso en este caso se concibe como una especie de principio activo que no desencadena los resultados esperados. Los padres fundadores estadounidenses, los padres de la patria latinoamericanos o los revolucionarios septembrinos no concibieron un modelo de Estado-nación voluntarista en estado puro, ya que la visión orgánica y de homogeneidad cultural era mucho más efectiva a la hora de asegurar la solidez nacional ${ }^{31}$. En este sentido, no serían contradictorias las referencias a una secularización repleta de referentes religiosos. Evidentemente, desde la premisa de que todo cambio político y modernizador debe ser visible, muchas medidas y proclamas secularizadoras fueron concebidas como garantía de que "las revoluciones si no han de ser movimientos militares y simples motines, se han de dar a conocer por sus resultados, beneficios para la libertad y adelantos de la humanidad" ${ }^{32}$. Se consideraron una especie de "manantial primero", fácilmente distinguible respecto a otras "libertades dispersas, desgreñadas"33. Estamos ante una narrativa elaborada por la intelligentsia cultural y política americana y española, con una indiscutible visión eurocéntrica, que adapta los ideales de progreso a sus respectivos contextos ${ }^{34}$. El resultado es una retórica que presenta el ideal revolucionario como "discontinuidad fuerte" entre un mundo anterior, arcaico, condenado a desaparecer y un horizonte nuevo,

\footnotetext{
${ }^{30}$ GUERRA, François-Xavier, Modernidad e independencias, Bilbao, Mapfre, 1992, p. 13.

${ }^{31}$ MARIENSTRAS, Élise, Les mythes fondateurs de la nation américaine..., pp. 18-45.

${ }^{32}$ La Tertulia, 21 de julio de 1869.

${ }^{33}$ La América, 13 de noviembre de 1868.

${ }^{34}$ MARTIN, David, «Introduction», en On Secularization, Burlington, Ashgate Publishing 2005.
} 
inherente al propio devenir revolucionario, pero también sujeto a unas "líneas de continuidad" que no necesariamente están vinculadas al pensamiento más conservador. La nueva concepción de soberanía no era suficiente para asegurar la adhesión popular al Estado-nación de manera que los referentes religiosos, en mayor o menor intensidad, evitaban la imagen de vacío y ofrecían la posibilidad de "remontar el fraccionamiento de la sociedad como comunidad" 35 . La secularización no es interpretada entonces como la progresiva e inevitable desaparición de la religión bajo los compases de la modernidad, sino como un proceso vivo, sujeto a una constante adaptación a la realidad social del momento ${ }^{36}$. La aparente confrontación entre el triunfo de la "interpretación revolucionaria del progreso”, en los países más secularizados, y su fracaso en aquellos que se mostraron más resistentes a su avance, deja paso a una imagen conciliadora. Historia y modernidad constituyen la piedra angular de un discurso identitario que no rompe con la idea de providencia ni con un "cristianismo (que) lejos de estar lejos del progreso, es su causa”37. En el trasfondo de esa interpretación subyace la idea apuntada por Annino para Latinoamérica de que el "sueño inglés" constituía en realidad el verdadero objetivo de muchos liberales que sin embargo lo persiguieron en algunos momentos "con instrumentos franceses”38.

El análisis de procesos secularizadores en contextos sociopolíticos distintos resulta complejo. Gaetano señala que ni siquiera los espacios en los que la laicidad se presenta como eje de identidad nacional pueden estudiarse a partir de interpretaciones simplificadoras ${ }^{39}$. Banclarte indica que tanto en España como en América latina, con todos los matices que es necesario incorporar para un espacio tan amplio, la idea de laicidad adquirió un carácter “combativo y anticlerical” entre 1850 y $1950^{40}$, precisamente

\footnotetext{
${ }^{35}$ SAUQUILLO, Julián, “Revolución y secularización”, en Isegoría, 39 (2008), pp. 16-17.

${ }^{36}$ DI STEFANO, Roberto, "Religion, Politics and Law in 19th Century Latin America", Debatte, 16 (2010), p.119.

${ }^{37}$ CAPELLÁN DE MIGUEL, Gonzalo, “¿Mejora la humanidad? El concepto de progreso en la España liberal”, en SUÁREZ CORTINA, Manuel, (ed.), La redención del pueblo. La cultura progresista en la España liberal, Santander, Universidad de Cantabria, 2006, pp. 5561.

38 ANNINO VON DUSEK, Antonio, "Imperio, Constitución y diversidad en la América hispana”, en Ayer, 70 (2008), p. 30.

39 GAETANO, Gerardo (dir.), El “Uruguay laico”. Matices y revisiones, Montevideo, Santillana, 2013, p. 13.

40 BLANCARTE, Roberto, “América Latina. Entre pluriconfesionalidad y laicidad” en Civitas. Revista de Ciências Sociais, v.11, 2 (2011), p. 184.
} 
porque aparece ligada al concepto de revolución como cambio total ${ }^{41} \mathrm{y}$ a la construcción de una identidad fundamentada en la soberanía nacional y la democratización frente a la monarquía y la Iglesia. Sin embargo, en muchos estados americanos y europeos la Iglesia fue considerada una institución civilizadora que junto al ejército o la escuela, podía difundir valores cívicos y también cristianos ${ }^{42}$. Así pues, en ambas orillas del Atlántico la (in)discutible inherencia del catolicismo a la esencia nacional condicionó la construcción de los relatos de progreso como armazón identitario.

\section{2. ¿SECULARIZACIÓN FRENTE A CATOLICISMO COMO ESENCIA NACIONAL?}

En un espacio cultural tan amplio como el que aquí analizamos el catolicismo actuó como una fuerza de nacionalización poderosa, aunque presenta importantes matices. Unía a su capacidad histórica de penetración en el tejido social, una narración del ser nacional ya consolidada, fundamentada en las esencias y las costumbres amalgamadas en una especie de patriotismo innato. Tuvo un papel fundamental en la configuración de las repúblicas americanas ante el vacío jurídico-institucional dejado por la Monarquía tras la independencia y actúo como nexo de unión entre "el territorio prenacional y el nacional" ${ }^{43}$. Aunque puede hablarse de una extraordinaria precocidad en la experiencia liberal de la América hispánica, comparada con Europa, la preeminencia de la Iglesia católica fue indiscutible debido a la propia vertebración social y territorial en la que el catolicismo se concebía como una especie de material parental. Así pues, al concepto de ciudadanía derivado de la independencia se le otorga "carne y hueso" vinculándolo a la comunidad local, como fuente de derechos políticos y a la parroquia como referencia de la misma. El liberalismo latinoamericano primero fue "comunitario y católico, porque reconoció a la comunidad local el hecho de ser una sociedad natural, preexistente al orden político" vinculada al "concepto de vecindad" ${ }^{44}$. François-Xavier Guerra

\footnotetext{
${ }^{41}$ ARTOLA, Miguel, “El siglo XIX, un balance político”, en CORTAZAR, Guillermo (ed.), Nación y Estado..., p. 94.

${ }^{42}$ GIMENEZ BELIVEAU, Verónica "Jerarquías eclesiásticas, nación y espacio público en Argentina”, en BLANCARTE, Roberto (coord.), Los retos de la laicidad y de la secularización en el mundo contemporáneo, México, Colegio de México, 2008, p. 225.

${ }^{43}$ ANNINO VON DUSEK, Antonio y GUERRA, François-Xavier (coords.), Inventando la nación..., pp. 683-686.

${ }^{44}$ ANINO VON DUSEK, Antonio, "Imperio, Constitución y diversidad en la América hispana”, en Ayer, 70 (2008), p. 31; DI STEFÁNO, Roberto, “Religion, politics and law
} 
señala que la particular "inserción del continente en los paradigmas conceptuales occidentales” y el propio origen de las repúblicas, justifica la necesidad de mantener el catolicismo para minimizar "los riesgos de la imposición súbita de los principios republicanos” ${ }^{45}$. Se asumió la orfandad de soberanía junto a la república, considerada como opción necesaria e ineludible más que un ideal de sistema de valores colectivos y alternativos. En las décadas siguientes los vaivenes políticos entre liberales y conservadores impactaron en los avances y retrocesos de las políticas secularizadoras. Blancarte considera Colombia un caso paradigmático en este sentido: en 1863 la nueva constitución liberal era una prueba de “ateísmo” porque “desconocía la personalidad jurídica de la Iglesia”; veinte años después, la situación fue revertida absolutamente por los conservadores con la aprobación de una nueva constitución que reconocía a la Iglesia una influencia plena en todos los ámbitos de la vida política y social ${ }^{46}$. Chile o Uruguay son presentados como estados “excepcionales”, ya que lograron vertebrar un referente identitario en torno a conceptos como ciudadanía o laicidad, bajo el impulso integrador del Estado y las elites ilustradas ${ }^{47}$. Sin embargo el estereotipo no puede ocultar las dificultades en la maduración de una "sacralización de lo cívico"48.

En España la presencia social de la Iglesia y la fuerza de las posiciones más ultramontanas entre su jerarquía ${ }^{49}$ no fue obstáculo para su supervivencia en la coyuntura revolucionaria de 1868, ante un posible vacío identitario que los valores republicanos no consiguieron superar como alternativa reconocible y homogénea. Las "versiones cristianizadas” del

in 19th Century Latin America, Rechtsgeschichte (2010), pp. 117-120. MÁRQUEZ ESTRADA, José Wilson, "Las Estrategias Políticas y Culturales en el Proceso de Formación de la Ciudadanía en Colombia: 1810-1860”, Anuario de Historia Regional y de las Fronteras, 16 (2011), p. 300.

${ }^{45}$ GUERRA, François-Xavier, "Le Peuple Souverain: Fondements et logiques d'une fiction (XIXeme siecle)”, en Quel Avenir pour la Démocratie en Amérique latine, Paris, Editions du CNRS, 1989, citado en STUVEN, Ana María (ed.), La religión en la esfera pública chilena: ¿laicidad o secularización? Santiago Chile, Ed. Universidad Diego Portales, 2014, p. 14.

46 BLANCARTE, Roberto, "Laicidad y Laicismo en América latina”, en Estudios sociológicos XXVI, 76 (2008), p. 153.

${ }^{47}$ GAETANO, Gerardo (dir.), El “Uruguay laico”. pp. 28-38 y 369-374.

48 CID, Gabriel, "Ritos para una nueva legitimidad. Ceremoniales constitucionales y republicanismo (1812-1833)”, en Historia Crítica, 47 (2012), pp. 17- 43.

${ }^{49}$ CASTRO ALFIL, Demetrio, "La indefinida secularización de la España Isabelina. No Estado laico ni sociedad profana, en SUÁREZ CORTINA, Manuel, Secularización y Laicismo en la España contemporánea, Santander, Sociedad Menéndez Pelayo, 2001, pp. 76-77. 
catolicismo proyectaron un ideal secularizador vinculado a valores trascendentales, aunque tuvo escasa consistencia frente a un poderoso entramado católico ${ }^{50}$. Asumían que el progreso era una corriente "inerte, latente, que (había despertado) para guiar el devenir nacional”51 en un "mundo en marcha"52 en el que ningún "adelanto físico, moral, intelectual, político, económico, social” se había producido sin entrar "en guerra abierta

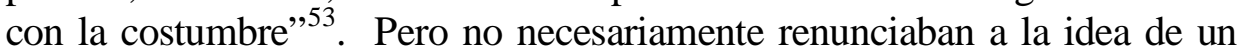
Dios que "ha querido que el día de hoy no se parezca al de ayer, que el siglo de ahora no sea repetición monótona del anterior" ${ }^{54}$ porque la "humanidad es llevada por la senda del progreso de la mano del mismo Dios” ${ }^{\text {"55 }}$ ya que es una "ley divina" 56.

Con Weber se consolida una interpretación dual de la secularización entre un mundo protestante y moderno y otro católico y retrógrado ${ }^{57}$. La supuesta incapacidad de las sociedades católicas para adentrarse en la modernidad respondía a una especie de esencia nacional. Las pulsiones del anticlericalismo más violento o el atraso socioeconómico de los países católicos se explican por un sustrato "impermeable" al impacto modernizador. Pero el análisis de la nación como objeto en construcción permite superar las simplificaciones inherentes a ese modelo y apreciar los intentos de las elites progresistas por combinar modernidad y tradición. Los americanos querían evitar el salto en el vacío tras la independencia, para no

${ }^{50}$ GINER, Salvador, “La religión civil”, en DÍAZ -SALAZAR y GINER, Salvador (eds.), Formas modernas de religión, Madrid, Alianza Universidad, 1994, p. 131.

51 GARABEDIAN, Marcelo H., SZIR, Sandra M. y LIDA, Miranda (eds.), Prensa Argentina siglo XIX. Imágenes, textos y contextos, Buenos Aires, Teseo, 2009, pp. 1-52.

52 CALDERÓN LLANES, José, "Estudios sobre la religión”, en La Revolución, 30 de diciembre de 1869.

53 «Las leyes y las costumbres La federación y la libertad de cultos”, en El Siglo Diez y Nueve, México, 30 de marzo de 1857.

54 ECHEVERRÍA Esteban, Dogma socialista, en Obras completas de D. Esteban Echeverría, T IV, Buenos Aires, Imprenta y Librería de mayo, 1873, p. 88.

55 RUBIO, Carlos, Teoría del Progreso, folleto escrito en contestación al que con el título de "La fórmula del progreso" ha publicado D. Emilio Castelar por Carlos Rubio, Madrid, Imp. Manuel de Rojas, 1859, p.18.

56 “El Norte político”. Panfleto de propaganda electoral escrito por LAGIER, Ramón el 11 de enero de 1869. Archivo Municipal de Elche, Tesoro Histórico de Pedro Ibarra, 18001900 .

${ }^{57}$ El propio Weber afirma al final de su obra la necesidad de introducir matices y evitar las simplificaciones. WEBER, Max, La ética protestante y el espíritu del capitalismo, Edición original 1904/1905, Edición electrónica, 2009, www.laeditorialvirtual.com.ar, pp. 66-68. 
caer en "la pesadilla de una sociedad anónima" y sin identidad ${ }^{58}$. Los revolucionarios españoles del 68 buscaban igualmente una nueva identidad que sustituyera la imagen de una España lastrada por la corrupción y el oscurantismo.

\section{LOS PADRES DE LA PATRIA Y “LAS PALABRAS DE COLORES" 59}

Tourain define la nación como "la forma política de la modernidad, porque sustituye las tradiciones, las costumbres y los privilegios por un espacio nacional integrado, reconstruido por la ley que se inspira en los principios de la razón”. En la época que nos ocupa el ideal de progreso constituye el eje teleológico que legitima su materialización y la revolución es el motor de esa sustitución. Pero hablamos de estructuras conceptuales construidas con fines prácticos que buscan legitimar una nueva identidad nacional. En ellas puede apreciarse una idea modernidad sustentada por el desarrollo económico y otra en la que el Estado no es "gestor" sino "creador de la modernidad". En el primer caso el discurso identitario incorpora los planteamientos universalistas del progreso humano como algo natural. En el segundo, la "mezcla entre nacionalismo y modernismo adopta formas variables", en un "ser nacional más modernizador que moderno". Es una construcción "invertida" fundamentada en un universalismo racional que paradójicamente parte de "lo viejo" para hacer "lo nuevo",60. Gramsci lo explica como la construcción de una identidad nacional desligada del desarrollo económico local y por tanto limitada a reflejar el avance de otros países que envían a la periferia ideas e imágenes que sí derivan de un desarrollo productivo real. Hablamos entonces de una "ilusión histórica" racionalizada sobre la experiencia de otros. El papel de los intelectuales, vinculados a labores de gobierno, es clave en su difusión. Con ellos el "Estado cambia de aspecto", transformándose en un "absoluto racional" cuya función histórica está definida en el aparato discursivo como absoluta $^{61}$. Bénéton, señala que las transformaciones semánticas son reveladoras para entender el proceso. Así, aunque la retórica radical en torno

\footnotetext{
${ }^{58}$ MARTÍNEZ, Frédéric: El nacionalismo cosmopolita..., p. 21.

59 Es una expresión utilizada por José MARTÍ para referirse a los discursos vacíos de contenido en La Revista Ilustrada de Nueva York, 10 de enero de 1891.

${ }^{60}$ TOURAINE, Alain, Crítica de la modernidad, Madrid, Temas de hoy, 1993, pp. 178-183.

${ }^{61}$ GRAMSCI, Antonio, Cuadernos de la cárcel. Edición crítica del Instituto Gramsci a cargo de Valentino Gerratana. T.I. Cuaderno I, nota 150. México, Ediciones Era, 1981 p. 189.
} 
al cambio siempre está presente y se ajusta perfectamente al propio concepto de progreso, universal, irreversible y en cierto sentido nivelador, podemos distinguir entre un ideal de progreso por "acumulación”, que se resiste a perder los anclajes culturales, y un progreso por "sustitución”, en el que prevalece el carácter autónomo, dinámico o creador ${ }^{62}$. Ambas líneas se entrecruzan en los discursos analizados: por un lado, las esencias, es decir, aquello que singulariza a la nación respecto a otras, y por otro, los referentes externos que permiten conectar con una ruta de futuro universal en la que encaja perfectamente una concepción cristiana de la historia, sujeta a un plan previo y trascendente ${ }^{63}$.

Los próceres americanos eran "blancos, criollos y católicos" ${ }^{\text {"64 }}$. Su ideal de nación moderna debía permitir la transferencia de legitimidad de la monarquía a la república excluyendo cualquier referencia a una nación americana prehispánica $^{65}$. Aunque en un principio el liberalismo americano mostró un paternalismo civilizador y cierta benevolencia hacia la población indígena, la imagen del buen salvaje rousseauniano derivó hacia su inferioridad moral. El papel integrador de la Iglesia también evolucionó desde su misión “civilizadora” a la intervención activa en los procesos de aculturación que sufrió la población indígena ${ }^{66}$. El escritor español Juan Alonso y Eguilaz incide precisamente en las diferencias raciales para hablar del progreso. Señala que "los indios indígenas van desapareciendo providencialmente porque aquella región del globo necesita progreso, y ellos, por su naturaleza eran y son inhábiles para ir mucho más lejos del grado de civilización en los que los hallaron los primeros emigrantes

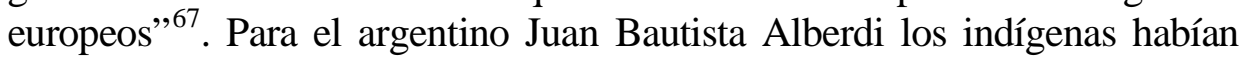
heredado ese españolismo, que representaba "todo lo que es retrógrado" y constituían "el mayor obstáculo al progreso". Sin embargo distinguía entre

62 BÉNÉTON, Philipe, Historie de mots: culture et civilisation, Paris, Presses de la Fondation Nationale des Sciences politiques, 1975, pp. 12-68.

${ }^{63}$ NISBET, Robert, Historia de la Idea de Progreso, Ed. Gedisa, Barcelona, 1996; Jesús ROGADO, "Historia, teleología y religión”, en Revista académica de Relaciones internacionales, 8 (2008), pp. 10-14.

${ }^{64}$ CALDEVILLA DOMINGUEZ, David, "Las independencias americanas: historiografía, prensa e identidad criolla, en Historia y Comunicación Social, 16 (2011), p. 21.

${ }^{65}$ ANNINO VON DUSEK, Antonio, “Imperio, Constitución y diversidad.”, pp. 23-56.

${ }^{66}$ PEÑA, María Antonia and ZURITA, Rafael, "The peruvian native and the conception of liberal citizenship in the Latin American context”, en SIERRA, María, Enemies Within: Cultural Hierarchies and Liberal Political Models in the Hispanic World, Newcastle, Cambridge Scholars Publishing, 2015, pp. 11-13.

${ }^{67}$ La América, 13 de noviembre de 1868. 
una “joven España, hermana nuestra, porque venimos de un mismo siglo” y la "España vieja, la madrastra nuestra”. ${ }^{68}$ Esteban Echevarría también aludía en los años treinta a una "América revolucionaria envuelta todavía en los pañales de la que fue su madrastra" porque aunque sus "lazos ya no nos oprimen, sus tradiciones nos abruman" ${ }^{\text {"69 }}$. El escritor uruguayo José Pedro Valera regresa a la imagen del indio ocioso que encarna la falta de empuje inoculado por la "madre España”, frente a la "gran república del Norte" y la "raza sajona" que es la "raza del porvenir"70.

Los indios no, pero el ideal republicano sí era un referente válido para la nación e incluso el continente ${ }^{71}$. La república materializaba el dinamismo americano porque cuando "la República camina" la "libertad progresa", "el catolicismo cae” y "los imperios se bambolean”. Para Varela era la fórmula que había convertido a Uruguay en "señora del mundo" entre las naciones más avanzadas" "72. También Europa, y especialmente Francia, eran los referentes buscados por escritores y políticos que al mismo tiempo deseaban proyectar una originalidad americana. Alberdi señala en fechas muchas tempranas que "el hecho de la emancipación americana supone el pensamiento de la emancipación americana" e indica que "los gigantes de la patria no son los gigantes de la retórica” porque la grandeza se prueba con "los hechos", . En la misma línea se expresa posteriormente el escritor venezolano Andrés Bello que reivindica "un pensamiento propio" para conseguir apropiarse de "su espíritu" ". A finales de siglo la imagen de la España "madrastra” evoluciona, coincidiendo con el viraje conservador de muchos gobiernos latinoamericanos. Es una nueva mirada identitaria que

\footnotetext{
${ }^{68}$ ALBERDI, Juan Bautista: “Reacción contra el españolismo”, La Moda. Gacetín semanal de Música, de Poesía, de Literatura, de Costumbres, 14 de abril de 1838.

${ }^{69}$ ECHEVERRÍA, Esteban, Dogma socialista..., p. 88.

70 Textos de José Pedro VARELA de 1865 citados por ACOSTA, Yamandú, “José Pedro Varela. Los escritos de La Revista Literaria en la perspectiva de la función utópica del discurso", en VERMEREN, Patrice y MUÑOZ, Marisa (comp.), Repensando el siglo XIX desde América latina y Francia: Homenaje al filósofo Arturo A. Roig, Buenos Aires, Colihue, 2009, pp. 446-451.

${ }^{71}$ MORENO LUZÓN, Javier, "Entre el progreso y la Virgen del Pilar. La pugna por la memoria en el centenario de la Guerra de la Independencia”, Historia y Política, 12 (2004), p. 42.

72 Citado por ACOSTA, Yamandú, “José Pedro Varela. Los escritos..., pp. 446-451.

${ }^{73}$ ALBERDI, Juan Bautista, "La generación presente a la faz de la generación pasada”, El Iniciador, junio de 1838 (Montevideo), en Obras Completas, Buenos Aires, 1886.

${ }^{74}$ BELLO LÓPEZ, Andrés, "Modo de estudiar la historia”, en El Araucano, Santiago de Chile, 1848.
} 
cuestiona a franceses y anglosajones como referentes y recupera los vínculos con la antigua metrópoli. La escritora colombiana Soledad Acosta Samper constituye un buen ejemplo. Para ella "ninguna enseñanza moral se desprende de la historia de los antiguos indígenas", que deberían ser considerados sólo como "una curiosidad etnográfica" y no "como un conocimiento útil”. Si la civilización procede de Europa fueron los españoles "los progenitores espirituales de toda la población. Así pues, a éstos debemos atender con preferencia, si deseamos conocer el carácter de nuestra civilización" 75 .

Los republicanos españoles también buscaban identificar a los culpables del atraso español, aunque en este caso no existía una metrópoli responsable sino dos instituciones: la monarquía y la Iglesia. Roberto Robert considera que la influencia del catolicismo, la Inquisición y la "piadosa” Isabel la Católica, "una mujer en el trono" y como tal, débil y poseída de ciertos escrúpulos femeniles", fueron determinantes en la ignorancia y la postergación del "pueblo español, eminentemente artístico y religioso", que encontraba en el templo "misa y comedia en una pieza"76. Garrido se pregunta "¿de qué serviría habernos librado de esa mujer insensata, de esa agente de la opresión, del empobrecimiento y de la corrupción, si dejamos en pie el poder real, efectivo, inmenso, hidra de mil cabezas y de millones de garras, cuya enorme panza aplasta al desgraciado pueblo romano?”77. La única "cura” era la república, "forma política idónea” nacida del "derecho natural” y por tanto "ideal racional de construcción civil” capaz de evitar "un retroceso moral”78. Desde la España revolucionaria el escritor Luis Corrales utiliza referentes religiosos al definirla como el verdadero dogma Evangélico escrito en el Gólgota con la preciosa sangre del Redentor del mundo $^{79}$. Dos años después del estallido revolucionario la llegada del rey Amadeo a España, imagen de monarca demócrata y moderno, fue considerada una traición al pueblo por parte de "nuestros regeneradores"

\footnotetext{
${ }^{75}$ ACOSTA SAMPER, Soledad, Biografías de hombres ilustres o notables, relativas a la época del descubrimiento, conquista y colonización, Bogotá 1883. p. 2.

${ }^{76}$ ROBERT, Roberto, Los cachivaches de antaño, Madrid, 1869, pp. 15-23 y 245.

${ }^{77}$ GARRIDO, Fernando, "La revolución religiosa” (folleto publicado en La Discusión, Madrid, 8 de octubre de 1868.

${ }^{78}$ ROGADO, Jesús, “Historia, teleología y religión”, Relaciones Internacionales, 8 (2008), p. 12.

79 “La República y el Evangelio”, en Revista Federal. Enciclopedia semanal de ciencias, artes, agricultura, industria, comercio, literatura, noticias, teatros y modas (Madrid), 17 de abril de 1870 .
} 
que apartaban al país del "verdadero progreso" ${ }^{80}$. Castelar, desde esa misma perspectiva teleológica, considera que la república culmina un largo proceso, cuyo triunfo se debía a las circunstancias y a la "conspiración de la sociedad, de la Naturaleza, de la Historia”81. Pero la república no sólo era una idea. Manuel de la Revilla alude precisamente a la experiencia de "varias Repúblicas hispano-americanas, que tienen nuestro origen y que hablan nuestra hermosa lengua” para no repetir "sus tristes experiencias" 82 .

Si nos centramos en la valoración que los constructores de la nación hacían de la secularización y su relación con el progreso encontramos matices interesantes en ambos lados del Atlántico. Para los positivistas como Gabino Barreda cualquier religión es un "conjunto de esperanzas fantásticas e imaginarias", pero "semejante cimiento" no permite "construir un edificio

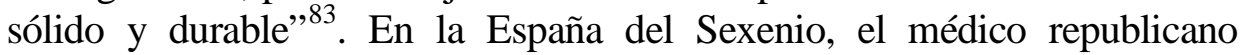
Francisco Suñer y Capdevila, autor del famoso folleto Dios, publicado en 1869, considera que el ateísmo es la única opción posible para consolidar el progreso: "En lugar de Iglesias, escuelas; en lugar de curas, maestros; en lugar de misterios, las leyes indeclinables y fatales de los hechos" ${ }^{\text {" } 4}$. Jorge Lagarrigue, también médico y filósofo positivista chileno, cree sin embargo que el cambio debe ser gradual. Su "religión demostrable" es la secuencia lógica del progreso pero insta a "los más ciegos revolucionarios” a que comprendan que "la sociedad no puede vivir sin religión". Por tanto, no es necesario enfrentarse al catolicismo sino dar una "dirección más elevada" a "los hábitos religiosos” porque el teologismo” se acercará naturalmente a "la realidad” ${ }^{85}$.

La distancia entre "experiencia y expectativa” que establece Koselleck en su ya clásica obra sobre los conceptos es un esquema válido para comprender el funcionamiento de la secularización en los discursos de

\footnotetext{
${ }^{80}$ Revista Federal, 23 de enero de 1870, Vid. DE LA FUENTE MONGE, Gregorio, Los revolucionarios de 1868. Elites y poder en la España liberal, Madrid, Marcial Pons, 2000.

${ }^{81}$ DSC, Legislatura, 1873, 11 de febrero.

82 DE LA REVILLA, Manuel, Historia y defensa de la Declaración de la prensa republicana, Madrid, Imprenta de La Discusión, 1870, p. 16.

${ }^{83}$ BARREDA, Gabino, "De la educación moral” (El Siglo XIX, 3 de mayo de 1863), en FUENTE MARES, José (ed.), Estudios, México, Universidad Nacional Autónoma, 1941, pp. 111-125.

84 SUÑER Y CAPDEVILA, Francisco, "La caída del papado", Anuario Republicano Federal, Madrid, 1870, pp. 448-458.

85 LAGARRIGUE ALESSANDRI, Jorge, "Positivismo y catolicismo" (Conferencia en Santiago de Chile, 1884), en ZEA, Leopoldo (comp.), Pensamiento positivista latinoamericano, 1980, Biblioteca Ayacucho, pp. 407-426.
} 
progreso. Existe una tensión abierta entre ambos términos ya que cuanto menor es el contenido de experiencia, es decir de la consolidación de los ideales revolucionarios, mayor es la expectativa en la semántica del cambio histórico, lo cual se traduce en discursos que priman el "deber ser abstracto" no objetivado. El progreso se convierte entonces en un concepto que vuelve hacia lo concebido, casi como mera "anticipación". El punto de partida es "la experiencia de la desaparición de la experiencia”, es decir, la revolución y la idea de ruptura, que precisa despertar y mantener nuevas expectativas, aunque apunte más allá de aquello que se puede cumplir empíricamente ${ }^{86}$. La inserción de la secularización en la narrativa de cambio aspira a convertirse en parte de esa experiencia que permite continuar planteando expectativas fundamentadas en sus efectos beneficiosos para el desarrollo. El revolucionario Fernando Garrido señala en este sentido la buena acogida que la población había dispensado a las medidas secularizadoras aprobadas, "una irrecusable demostración del progreso de las ideas en las entrañas del país”87. En la misma línea el político republicano Pi y Margall considera que ese arraigo era consecuencia de los propios fundamentos racionales de la revolución, “como deducción lógica”88. La aprobación de la ley de matrimonio civil en 1870 es un ejemplo de este tipo de argumentos. Aunque no suponía ninguna traba para la celebración del matrimonio religioso ${ }^{89}$, fue objeto de enconadas polémicas. Sus defensores lo consideraban una "gran conquista de la revolución moderna”. Desde Reus, primer municipio en aprobar su práctica en España, se utilizó directamente el concepto de "secularización” para señalar que las uniones civiles evidenciaban "cuan manifiesta" es "la tendencia del espíritu público a la completa secularización

\footnotetext{
${ }^{86}$ KOSELLECK, Reinhart, En futuro pasado. Para una semántica de los tiempos históricos, Barcelona, Paidos, 1993, pp. 328-357.

${ }^{87}$ GARRIDO, Fernando, La Restauración Teocrática. Progresos y decadencia del catolicismo en España, desde nuestros desde fines del siglo XV hasta nuestros días, Imp. Salvador Manero, Barcelona, 1879, 204-212; En su obra Viajes del Chino Dagar-Li-Kaopor los países bárbaros de Europa, España, Francia, Inglaterra y otros, traducido del chino al castellano por el ermitaño de las Peñuelas, Madrid, 1883, p.135, considera que la pervivencia del catolicismo es un síntoma de paganismo.

${ }^{88}$ PI Y MARGALL, Francisco, La Reacción y la Revolución, Estudio preliminar y notas críticas a cargo de Antoni JUTGLAR, Barcelona, Anthropos, 1982, pp. 145-146.

89 MARTÍNEZ ALCUBILLAS, Marcelo, Diccionario de la administración española. Compilación de la novísima legislación de España en todos los ramos de administración pública, Madrid, 1923.
} 
de todas las instituciones sociales" 90 . La libertad de cultos también se presenta como signo de modernidad en la narrativa de progreso, aunque observamos claras variaciones entre España y América. Garrido la considera un símbolo de una verdadera "revolución religiosa" y una "cuestión vital" para la "Nación" porque es la madre de todas las libertades capaz de "reconciliar a España completa y definitivamente con la civilización

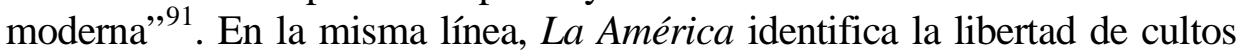
con el primer paso en la labor de "levantar el edificio de nuestra regeneración“992. La esperada llegada “masiva” de protestantes a España y su labor proselitista desencadenó gran expectación y no pocas reticencias respecto a una confesión que "estaba de capa caída" puesto que "una protesta no es una religión”" ${ }^{\text {"3 }}$ En general muchos republicanos aprovecharon la apertura de capillas o el anuncio de charlas "de la palabra evangélica"94 para visibilizar la fuerza del cambio acometido por la Gloriosa. En América la tolerancia de cultos también se interpretó como un "principio eminentemente civilizador" ${ }^{95}$ desde fechas muy tempranas. Pero además estaba relacionada con la atracción de inmigración europea y americana. Al ideal regenerador y modernizador en abstracto se sumaba una visión del progreso económico y social. En Nueva Granada, ya en 1825, se consideraba un requisito imprescindible "si queremos morigerar nuestra población, que esta crezca rápidamente, que cien pabellones diversos tremolen en nuestro puertos y que veamos en ellos los productos de toda la tierra”96. Alberdi también habla de prosperidad y de la necesidad de cortar con el pasado colonial. La "América española, reducida al catolicismo con exclusión de otro culto, representa un solitario y silencioso convento de

${ }^{90}$ GUELL Y MERCADER, El matrimonio civil según se practica en la ciudad de Reus. Guía y formulario para la celebración de este acto importante, Reus, Imprenta de Francisco Vidiella, 1869, pp. 7-17.

${ }^{91}$ GARRIDO, Fernando, “La revolución religiosa” (hoja suelta), en La Discusión, Madrid, 8 de octubre de 1888 .

${ }^{92}$ La América, 13 de noviembre de 1868.

${ }^{93}$ El Comercio, 1 de noviembre de 1868.

${ }^{94}$ APRACI DÍAZ, Antonio, Historia y raíces de los Bautistas en Alicante, Alicante, 1992, p. 62.

95 "Libertad de cultos" en La Gazeta del Comercio, Valparaíso, 2 de septiembre de 1844 citado en STUVEN, Ana María (ed.), La religión en la esfera pública chilena: ¿laicidad o secularización? Santiago Chile, Ed. Universidad Diego Portales, 2014, p. 195.

96 “Comercio”, en La Miscelánea, Bogotá, 20 de noviembre 1825, citado en COY SIERRA, Andrey Arturo, “Tolerancia religiosa en Bogotá” 1849-1854”, Historia Crítica, 33 (2007), p. 87. 
monjes”. El dilema para Argentina es: “o católica exclusivamente y despoblada; o poblada y próspera, y tolerante en materia de religión”. Traer a los anglosajones sin "su culto es traerlos sin el agente que los hace ser lo que son; a que vivan sin religión, a que se hagan ateos". No es posible mantener la intolerancia "en beneficio de nuestros primeros pobladores católicos” si se apunta hacia miras más “amplias y generosas”97.

Si nos detenemos en la educación también observamos diferencias en la argumentación de uno y otro lado. En las repúblicas americanas fue objeto de especial atención casi desde sus orígenes. Su relación con la secularización no obedece a una vaga nebulosa modernizadora, como sucede en muchos discursos del Sexenio, sino que tenía un fin político concreto: la uniformización para la "expansión del sistema representativo vinculado a la nación soberana", incluyendo todo el "espectro social y étnico"98. La secularización de la enseñanza se concibe como un instrumento de progreso y de integración estatal capaz de superar el pasado colonial, con la mirada puesta en nuevos referentes educativos europeos ${ }^{99}$. Sin embargo, también este apartado fue objeto de los vaivenes políticos. Marta Fernández destaca el caso de Perú y Ecuador en los años sesenta, con una Iglesia omnipresente en el Estado y en la sociedad, particularmente poderosa en materia educativa ${ }^{100}$. En cambio en esa misma época el liberalismo radical colombiano muestra su preocupación por los maestros de escuela que encarnan el ideal civil y laico en los pueblos frente a la antigua influencia de los curas de parroquia. Las escuelas normales formaban al "maestro/ciudadano", defensor del lenguaje cívico republicano y encargado de marcar distancia respecto a la tradición cultural católica ${ }^{101}$. La mayoría de intelectuales y políticos latinoamericanos, vieron en la

${ }^{97}$ ALBERDI, Juan Bautista, Bases: y puntos de partida para la organización política de la República Argentina. Buenos Aires, pp.52-43. Editado por Alberto Cruz en 1924 para costear un monumento honorífico.

98 QUIJADA, Mónica, BERNAND, Carmen y SCHNEIDER, Arnd, Homogeneidad y nación... pp. 36-38.

99 WEINBERG, Gregorio, "Ilustración y educación superior en Hispanoamérica” en Simposium Internacional sobre Educación e Ilustración. Dos siglos de reformas en la enseñanza, Madrid, MEC, 1988, p. .94.

${ }^{100}$ FERNÁNDEZ PEÑA, Marta, "El elemento religioso en el liberalismo iberoamericano: los casos de Perú y Ecuador”, en GONZÁLEZ, Damián, ÓRTIZ, Manuel y SISINIO PÉREZ GARZÓN, Juan (eds.) Actas del XIII Congreso de la Asociación de Historia Contemporánea, Cuenca, UCM, 2017, pp. 2448-2456.

${ }^{101}$ LOAIZA CANO, Gilberto, "El maestro de escuela o el ideal liberal de ciudadano en la reforma educativa de 1870”, en Historia Crítica, 34 (2007), pp. 62-91. 
educación el único medio para lograr "una nación unitaria y un poder estatal indiscutido" ${ }^{102}$, la "panacea a los males" para alcanzar al "cerrado grupo de países que se autocalificaban de progresistas”" ${ }^{103}$. Las palabras de Echevarría son reveladoras: "un pueblo no se transforma de un soplo, no cambia de hábitos sino después de una larga y laboriosa educación”. Es la única forma de "inocular" gradualmente "el elemento trino de la Democracia"104. En 1870, Barreda presenta su plan de estudios "sobre instrucción preparatoria" como la "llave del orden social y moral que tanto habemos menester" para erradicar la influencia de ciertas ideas religiosas y especialmente la huella de los jesuitas en la enseñanza ${ }^{105}$. El mismo año, el educador y sociólogo puertorriqueño Eugenio María de Hostos responsabilizaba a España de todos los problemas porque en vez de civilizar y educar al nuevo mundo "lo oprimió". Para el llamado ciudadano de América, la "revolución desinfectante" solo tendría éxito si llegaba "la fusión de razas y los "cruzamientos" con la educación como "esperanza del progreso"106. El Congreso Internacional Pedagógico, celebrado en Buenos Aires en 1882, muestra la importancia que se le daba como estrategia de integración estatal para modelar "un nuevo sujeto civil" ${ }^{107}$. La secularización de la enseñanza fue objeto de enconados debates entre los partidarios de una escuela laica, garantizada por el Estado y los sectores ultracatólicos reforzados por gobiernos conservadores ${ }^{108}$.

102 OSSENBACH SAUTER, Gabriela, "Estado y educación en América latina a partir de su independencia” (siglos XIX-XX), Revista Iberoamericana de Educación, 1 (2013), p. 96.

103 CORTÉS, Valeria, “Argumentos contra la modernidad laica del liberalismo” en CANO, Aurora SUÁREZ CORTINA, Manuel y TREJO, Evelia (eds.), Cultura liberal, México y España (1860-1930), Santander, Universidad de Cantabria, 2010, pp. 221-223.

${ }^{104}$ ECHEVERRÍA, Esteban, Discurso para la festividad del 25 de mayo de 1844 en Montevideo, Buenos Aires, 1873, p. 2 y 14. Francisco SOLANO señala su afán por "fundar una literatura que arraigara en identidad nacional”, encajando modernidad y una tradición propia, ajena a la herencia española”. "El precursor sin pedestal”, El País, 28 de mayo de 2016.

${ }^{105}$ BARREDA, Gabino, “Carta a Mariano Riva” (México, 10 de octubre de 1870), en ZEA, Leopoldo (Comp.): Pensamiento positivista latinoamericano T II, Caracas, Biblioteca Ayacucho, 1980, pp. 14-17.

${ }^{106}$ DE HOSTOS, Eugenio María, “Ayacucho” en El nacional, Lima, 9 de diciembre de 1870 y “El Cholo”, en La Sociedad, Lima, 23 de diciembre de 1870.

107 SÁNCHEZ, Cecilia, Una disciplina de la distancia. Institucionalización universitaria de los estudios filosóficos en Chile, Santiago de Chile, 1992, p. .33.

108 DELIO MACHADO, Luis, "El Congreso pedagógico de Buenos Aires de 1882”, en Anales de profesores del Instituto “Artigas”, 3 (2009), pp. 259-304. 
En la España revolucionaria, en cambio, no se definen estrategias claras para vertebrar un proyecto educativo coherente, aunque aparecieron muchas referencias a su poder taumatúrgico. La educación apenas fue objeto de diagnósticos profundos sobre cómo materializar su potencial transformador. Prevaleció una retórica ambigua: el ministro Ruiz Zorrilla hablaba de una enseñanza que armonice "lo oficial y lo privado hasta que llegue a ser innecesario lo primero por haber llegado la sociedad a la plena madurez". No había que "temer la propagación del error, puesto que la libertad genera sus propios mecanismos de defensa ${ }^{109}$. La prensa revolucionaria también siguió la misma línea argumental porque era necesario esperar "hasta que el desarrollo intelectual de nuestro país permita entregar a la iniciativa de los particulares el cuidado de generalizar la enseñanza" ${ }^{110}$. Los krausistas, en cambio, señalaban que la "revolución se está ocupando únicamente de lo exterior de la enseñanza, sin clara idea de lo que ella significaba" ${ }^{111}$. Algunos maestros abogaban por la participación del Estado en la educación, "sin ingerirse", pero ocupándose de las necesidades de la instrucción popular" ${ }^{\prime 12}$. Sin embargo, primó una amalgama argumental que reunía un anticlericalismo centrado en los abusos del clero a menores y apelaciones directas al pueblo inculto, responsable de su propia parálisis porque no lee, "no tiene conciencia” y así jamás podrá ser “soberano” de sus decisiones. En ella también se culpa al Estado del atraso español por vacilar respecto al reconocimiento de la libertad de cultos al continuar permitiendo una “enseñanza que embrolla a la razón”, promovida por un catolicismo invasor que sólo busca convertir al hombre en una "máquina dócil”. Los “errores cometidos en la enseñanza son fatales para el provenir de los pueblos"113. Aunque se derogó una ley extremadamente favorable para la Iglesia en materia educativa, considerada un obstáculo a "la ley del progreso

109 RUÍZ ZORRILLA, Manuel, "Decreto sobre la libertad de enseñanza”, Gaceta de Madrid, 22 de octubre de 1868, pp. 15-17.

${ }^{110}$ La América, 28 de octubre de 1868.

111 HEREDIA, Antonio, "La política docente del Sexenio (1868-1874) y su filosofía subyacente”, en Simposium Internacional sobre Educación e Ilustración. Dos siglos de reformas en la enseñanza, Madrid, MEC, 1988, pp. 435-436.

112 GARCÍA, Pedro de Alcántara, “La intervención del Estado en la instrucción popular”, en Boletín de la Universidad de Madrid, T II, 10 de noviembre de 1869, pp. 130-133, en DE LA FUENTE MONGE, Gregorio y SERRANO GARCÍA, Rafael, La revolución Gloriosa..., pp. 156-158.

${ }^{113}$ La Revolución, 30 de diciembre de 1869 y 12 de febrero de 1870. IBARRA, Pedro, Ramón Lagier. apuntes para ilustrar la biografía del bravo capitán del "Buenaventura", Elche, 1901, pp. 328-329. 
humano"114 y Castelar señaló el fin de la enseñanza religiosa y el nacimiento de la "escuela laica" ${ }^{\text {"15 }}$, todo formaba parte de la gestualidad revolucionaria. Si bien, la educación también se consideró una cuestión patriótica e identitaria ligada a la modernización no se supo encauzar en esa dirección. El Estado optó por dejarla en manos de la "ilustración y el patriotismo de las corporaciones populares" con "cuanto medios hallen a su alcance". Las escuelas para adultos constituyen un ejemplo revelador: el gobernador de la provincia de Alicante se dirigió a los alcaldes para que "exciten el celo de los profesores que hoy existen" y "que gratuitamente o bien con el premio de una pequeña gratificación" se encarguen de quienes "por su edad o circunstancias no pueden concurrir a las escuelas elementales"116. La prensa recoge muchos testimonios de maestros de primera enseñanza que ofrecen sus servicios sin remuneración alguna y que se sienten "poco menos que abandonados” y casi en vías de extinción ${ }^{117}$.

\section{CONCLUSIONES}

Cuando se trabaja sobre modelos es necesario enumerar unas características definitorias que cierren el paso a matices que podrían invalidarlos hasta convertirlos en la prueba de su "fracaso". El "modelo" secularizador constituye un ejemplo de la "multiplicidad de sentidos del término" y de la necesidad de buscar "otro término, concepto, modelo, que resulte más concreto y significativo" ${ }^{118}$. A lo largo del siglo XIX la secularización se incardina en los relatos de progreso diluyéndose, debilitándose, mezclándose o reinterpretándose para ajustarse a la realidad sociopolítica que la encuadra. La utilización de un concepto como éste en un contexto de cambio o revolución implica la emisión de una carga de fuerza que se diluye rápidamente si no procede de significados objetivados socialmente y por tanto subjetivados como reales ${ }^{119}$. La ductilidad es

114 “Decreto de 14 de octubre de 1868” en Colección legislativa de España, T. C, Ministerio de gracia y Justicia, Madrid, 1968, p, 320. Vid. COSSIO, Manuel Bartolomé, La enseñanza primaria en España, Madrid, 1897.

${ }^{115}$ DSC, Legislatura 1870, 2 de abril.

${ }^{116}$ BOP (provincia de Alicante). 5 de noviembre de 1868.

${ }^{117}$ Revista Federal, 6 de febrero de 1870.

${ }^{118}$ DE LA CUEVA MERINO, Julio, “Conflictiva secularización: sobre sociología, religión e historia”, Historia Contemporánea, 51 (2015), p. .379.

119 Como producto social y matriz "de todos los significados objetivados socialmente y subjetivamente reales”, en BERGER, Peter y Luckmann, Thomas, La construcción social de la realidad, Madrid, Amorrortu, p. 125-127. 
inherente a la secularización aunque se proyecte como idea-fuerza de la modernidad. En "estado puro" remite a una dinámica voluntarista, rupturista, que blande la novedad, el cambio y la conversión de la religión en una opción privada, presentándose como potencia de choque de la razón frente a las fuerzas de la reacción, encarnadas por la monarquía y la Iglesia $^{120}$. Pero toda ruptura implica la destrucción de referentes y una especie de "intemperie ideológica" que precisa encontrar un nuevo sucedáneo identitario $^{121}$. En este sentido las distintas narrativas nacionales de progreso recurren a una especie de "inflación retórica"122 para tejer un nuevo ropaje de continuidad. Desde esta perspectiva la secularización ya no se analiza en términos de un mayor o menor acercamiento a una supuesta ortodoxia sino que es pensada "problemáticamente", es decir, lo importante no es tanto su materialización sino la forma en que ha sido problematizada y reflejada en los discursos ${ }^{123}$. Como señala Veyne, "En este mundo, no jugamos al ajedrez con figuras eternas, el rey, el alfil: las figuras son aquello que las sucesivas configuraciones sobre el tablero hacen de ellas”"124. La resistencia de los referentes religiosos a desaparecer en las narrativas de cambio constituye una muestra de ese ropaje. Se asumen como "acervo formante" en una especie de "secularización nacional de la religión” ${ }^{125}$. En la mayor parte de los textos analizados se observa una aspiración a liberar el ideal de progreso del lastre de un catolicismo inmóvil pero sin dejarlo caer en el campo de unas expectativas cercanas al ateísmo o la increencia. Las "tonalidades" que adopta el cristianismo septembrino y latinoamericano en los mismos no se deben tanto a actitudes erráticas y poco precisas como al

${ }^{120}$ BAUBEROT, Jean, “Laïcité, laïcisation, sécularisation”, en DIERKENS, Alain (ed.): Problemes d'histoire des religions, Bruxeles, Institut d'ètude des religions et de la laïcité, 1993, p. 16.

121 PÉREZ VIEJO, Tomás, Nación, identidad nacional y otros mitos nacionalistas, Ediciones Nobel, Oviedo, 1999, pp.79-81.

$122 M^{\text {a }}$ FRADERA, Josep, “¿Se puede medir la nación?” en ROBLEDO, Ricardo, CASTELLS, Irene y ROMEO, $\mathrm{M}^{\mathrm{a}}$ Cruz (eds.), Orígenes del liberalismo. Universidad, política y economía, 2003, Salamanca, Universidad de Salamanca, p. 271.

${ }^{123}$ FOUCAULT, Michael: Theatrum Philosophicum, Barcelona, Anagrama, 1995, pp. 2728.

124 Es una frase de VEYNE de su Comment on Ecrit l'Historie. Suivi de Foucault Révolutionne l'Histoire, Paris, 1978, p. 236, citada por CHARTIER, Roger en El Mundo como Representación. Historia Cultural: entre práctica y representación, Barcelona, Gedisa, 1992, p. 42.

${ }^{125}$ Ideas del escritor Àngel Ganivet, en su Idearium español que recoge PAULINO, José, La secularización de la religión en el modernismo, 'Ilu, 3, 1998, pp. 214-219. 
intento de superar la fragmentación social derivada de la revolución o del cambio político. El referente cristiano se concibe entonces como salvaguardia del orden social y también permite sacralizar el ideal de progreso. Las "rupturas" revolucionarias o los vaivenes políticos aprovecharon su potencial simbólico acumulado para convertirlo en una especie de "metacategoría" capaz de encuadrar unos principios universales, depurados de la secular degradación católica, y conectar pasado y futuro ${ }^{126}$. Podría hablarse de un modelo de "república desincorporada" construida a partir de elementos como el cristianismo y el derecho para que el pasado no fuera olvidado sino "reinventado y modelado"127. Un modelo visible ya desde los primeros ensayos políticos latinoamericanos de 1808, con el objetivo de superar la crisis de legitimidad, hasta la España del Sexenio y su idea de una revolución impulsada por el propio Jesucristo, en un nuevo episodio de la lucha entre el "cristianismo humilde" contra la "teocracia", que justificaba la perfecta compatibilidad entre los "progresos de la civilización” y las “creencias divinas” ${ }^{128}$. En América, también se concibió el progreso como una consecución de "rompimientos" desde los primeros momentos de "orfandad política” hasta la construcción de las repúblicas en torno a un "ideal cristiano" que "no cabía en la unidad católica y la rompió", de manera que "la religión no ha desaparecido, sino que se ha transformado" ${ }^{22}$. Sin embargo, mientras en la España revolucionaria la secularización es concebida como una especie de "brazo armado" contra instituciones arcaicas, culpables del atraso y de la corrupción secular, como la Iglesia o la monarquía, en Latinoamérica se convierte a lo largo de todo el siglo en un componente identitario inherente al propio régimen republicano y a la modernidad, sin renunciar a los anclajes religiosos, frente a los valores más reaccionarios que representaba la vieja España.

\footnotetext{
${ }^{126}$ MORRA, Nello, “Laicismo”, Novissimo Digesto Italiano, Vol. IX, Torino, 1963, pp. 437-443.

${ }^{127}$ ENTIN, Gabriel, “De la república desincorporada a la república representada. El lenguaje republicano durante la revolución del Río de la Plata”, en Repensando el siglo XIX desde América Latina y Francia. Homenaje al Filósofo Arturo A, Roig, Buenos Aires, 2009, pp. 272-73.

${ }^{128}$ Revista Federal, $n^{\circ}$ 1, enero de 1870; BARCIA, Roque, Teoría del infierno o la ley de la vida, Imprenta de Manuel Galiano, Madrid, 1868, pp. 75 y 106; MANERO, Evaristo Estudios sobre la topografía médica de Alicante, Alicante, Carratalá y Gadea, 1883, p.148.

${ }^{129}$ El Nacional (Lima) 9 de diciembre de 1870; MARTÍ, José, La América, Nueva York, mayo de 1884, en Obras completas. Vol. III. La Habana, 1963, pp. 288-92
} 


\section{Bibliografía}

ACOSTA SAMPER, Soledad, Biografías de hombres ilustres o notables, relativas a la época del descubrimiento, conquista y colonización, Bogotá 1883.

ACOSTA, Yamandú, "José Pedro Varela. Los escritos de La Revista Literaria en la perspectiva de la función utópica del discurso", en VERMEREN, Patrice y MUÑOZ, Marisa (comp.), Repensando el siglo XIX desde América latina y Francia: Homenaje al filósofo Arturo A. Roig, Buenos Aires, Colihue, 2009, pp. 446-451.

ALBERDI, Juan Bautista, "La generación presente a la faz de la generación pasada”, El Iniciador, junio de 1838 (Montevideo), en Obras Completas, Buenos Aires, 1886.

ALBERDI, Juan Bautista, "Reacción contra el españolismo", La Moda. Gacetín semanal de Música, de Poesía, de Literatura, de Costumbres, 14 de abril de 1838.

ALBERDI, Juan Bautista, Bases y puntos de partida para la organización política de la República Argentina. Buenos Aires. Editado por Alberto Cruz en 1924 para costear un monumento honorífico.

ANNINO VON DUSEK, Antonio y GUERRA, François-Xavier (coords.), Inventando la nación, México, Fondo de Cultura Económica, 2003.

ANNINO VON DUSEK, Antonio: “Imperio, Constitución y diversidad en la América Hispana.”, en Ayer, 70 (2008), pp. 23-56

APARACI DÍAZ, Antonio, Historia y raíces de los Bautistas en Alicante, Alicante, 1992.

BARCIA, Roque, Teoría del infierno o la ley de la vida, Imprenta de Manuel Galiano, Madrid, 1868. 
BARREDA, Gabino, "De la educación moral” (El Siglo XIX, 3 de mayo de 1863), en FUENTE MARES, José (ed.) Estudios, México, Universidad Nacional Autónoma, 1941, pp. 111-125.

BARREDA, Gabino, Carta a Mariano Riva (México, 10 de octubre de 1870), en ZEA, Leopoldo (Comp.): Pensamiento positivista latinoamericano T II, Caracas, Biblioteca Ayacucho, 1980, pp. 14-17.

BELLO LÓPEZ, Andrés, "Modo de estudiar la historia”, en El Araucano, Santiago de Chile, 1848.

BÉNÉTON, Philipe, Historie de mots: culture et civilisation, Paris, Presses de la Fondation Nationale des Sciences politiques, 1975.

BLANCARTE, Roberto, “Laicidad y Laicismo en América latina”, en Estudios sociológicos XXVI, 76 (2008), pp. 139-164.

BLANCARTE, Roberto, “América Latina. Entre pluriconfesionalidad y laicidad” en Civitas. Revista de Ciências Sociais, v.11, 2 (2011), pp. 182206.

CALDERÓN LLANES, José, "Estudios sobre la religión”, en La Revolución, 30 de diciembre de 1869.

CALDEVILLA DOMINGUEZ, David, "Las independencias americanas: historiografía, prensa e identidad criolla, en Historia y Comunicación Social, 16 (2011), pp.13-31.

CASTRO ALFIL, Demetrio, "La indefinida secularización de la España Isabelina. No Estado laico ni sociedad profana, en SUÁREZ CORTINA, Manuel, Secularización y Laicismo en la España contemporánea, Santander, Sociedad Menéndez Pelayo, 2001.

CID, Gabriel, "Ritos para una nueva legitimidad. Ceremoniales constitucionales y republicanismo (1812-1833)”, en Historia Crítica, 47 (2012), pp. 17-43.

CORTÉS, Valeria, “Argumentos contra la modernidad laica del liberalismo" en CANO, Aurora SUÁREZ CORTINA, Manuel y TREJO, Evelia (eds.), 
Cultura liberal, México y España (1860-1930), Santander, Universidad de Cantabria, 2010, pp. 221-244.

COSSIO, Manuel Bartolomé, La enseñanza primaria en España, Madrid, 1897.

COY SIERRA, Andrey Arturo, “Tolerancia religiosa en Bogotá” 18491854”, Historia Crítica, 33 (2007), pp.74-97.

DE HOSTOS, Eugenio María, “Ayacucho” en El nacional, Lima, 9 de diciembre de 1870 y "El Cholo”, en La Sociedad, Lima, 23 de diciembre de 1870.

DE LA FUENTE MONGE, Gregorio, Los revolucionarios de 1868. Elites y poder en la España liberal, Madrid, Marcial Pons, 2000.

DE LA REVILLA, Manuel, Historia y defensa de la Declaración de la prensa republicana, Madrid, Imprenta de La Discusión, 1870.

DELIO MACHADO, Luis, "El Congreso pedagógico de Buenos Aires de 1882”, en Anales de profesores del Instituto “Artigas”, 3 (2009), p.259-304.

DI STEFANO, Roberto,: "Religion, politics and law in 19th Century Latin America , Rechtsgeschichte (2010), pp. 117-120.

ECHEVERRÍA, Esteban, Discurso para la festividad del 25 de mayo de 1844 en Montevideo, Buenos Aires, 1873.

ECHEVERRÍA Esteban, Dogma socialista, en Obras completas de D. Esteban Echeverría, T IV, Buenos Aires, Imprenta y Librería de mayo, 1873.

ENTIN, Gabriel, "De la república desincorporada a la república representada. El lenguaje republicano durante la revolución del Río de la Plata”, en Repensando el siglo XIX desde América Latina y Francia. Homenaje al Filósofo Arturo A, Roig, Buenos Aires, 2009, pp. 265-275.

FERNÁNDEZ PEÑA, Marta, "El elemento religioso en el liberalismo iberoamericano: los casos de Perú y Ecuador”, en GONZÁLEZ, Damián, 
ORTIZ , Manuel y SISINIO PÉREZ GARZÓN, Juan (eds.) Actas del XIII Congreso de la Asociación de Historia Contemporánea, Cuenca, UCM, 2017, pp. 2448-2456.

FOUCAULT, Michel, Las palabras y las cosas. Una arqueología de las ciencias humanas, Madrid, Siglo XXI, 1968.

FOUCAULT, Michael: Theatrum Philosophicum, Barcelona, Anagrama, 1995.

GAETANO, Gerardo (dir.), El “Uruguay laico”. Matices y revisiones, Montevideo, Santillana, 2013.

GARABEDIAN, Marcelo H., SZIR, Sandra M. y LIDA, Miranda (eds.), Prensa Argentina siglo XIX. Imágenes, textos y contextos, Buenos Aires, Teseo, 2009.

GARCÍA, Pedro de Alcántara, “La intervención del Estado en la instrucción popular”, en Boletín de la Universidad de Madrid, T II, 10 de noviembre de 1869, 130-133, en DE LA FUENTE MONGE, Gregorio y SERRANO GARCÍA, Rafael, La revolución Gloriosa: un ensayo de regeneración nacional (1868- 1874). Antología de textos, Madrid, Biblioteca Nueva, 2005.

GARRIDO, Fernando, "La revolución religiosa" (folleto publicado en $L a$ Discusión, Madrid, 8 de octubre de 1868.

GARRIDO, Fernando, La Restauración Teocrática. Progresos y decadencia del catolicismo en España, desde nuestros desde fines del siglo XV hasta nuestros días, Imp. Salvador Manero, Barcelona, 1879.

GARRIDO, Fernando, Viajes del Chino Dagar-Li-Kaopor los países bárbaros de Europa, España, Francia, Inglaterra y otros, traducido del chino al castellano por el ermitaño de las Peñuelas, Madrid, 1883.

GINER, Salvador, "La religión civil”, en DÍAZ-SALAZAR y GINER, Salvador (eds.), Formas modernas de religión, Madrid, Alianza Universidad, 1994, pp. 129-171. 
GRAMSCI, Antonio, Cuadernos de la cárcel. Edición crítica del Instituto Gramsci a cargo de Valentino Gerratana. T.I. Cuaderno I, nota 150. México, Ediciones Era, 1981.

GUELL Y MERCADER, El matrimonio civil según se practica en la ciudad de Reus. Guía y formulario para la celebración de este acto importante, Reus, Imprenta de Francisco Vidiella, 1869.

GUERRA, François-Xavier, "Le Peuple Souverain: Fondments et logiques d'une fiction (XIXeme siecle)", en Quel Avenir pour la Démocratie en Amérique latine, Paris, Editions du CNRS, 1989, en STUVEN, Ana María (ed.), La religión en la esfera pública chilena: ¿laicidad o secularización? Santiago Chile, Ed. Universidad Diego Portales, 2014.

HEREDIA, Antonio, "La política docente del Sexenio (1868-1874) y su filosofía subyacente", en Simposium Internacional sobre Educación e Ilustración. Dos siglos de reformas en la enseñanza, Madrid, MEC, 1988, pp. 431-438.

IBARRA, Pedro, Ramón Lagier. apuntes para ilustrar la biografía del bravo capitán del "Buenaventura”, Elche, 1901.

KOSELLECK, Reinhart, En futuro pasado. Para una semántica de los tiempos históricos, Barcelona, Paidos, 1993.

LAGARRIGUE ALESSANDRI, Jorge, "Positivismo y catolicismo" (Conferencia en Santiago de Chile, 1884), en ZEA, Leopoldo(comp.) Pensamiento positivista latinoamericano, 1980, Biblioteca Ayacucho, pp. 407-426.

LOAIZA CANO, Gilberto, "El maestro de escuela o el ideal liberal de ciudadano en la reforma educativa de 1870”, en Historia Crítica, 34 (2007), pp. 62-91.

MANERO, Evaristo Estudios sobre la topografía médica de Alicante, Alicante, Carratalá y Gadea, 1883.

MÁRQUEZ ESTRADA, José Wilson, "Las Estrategias Políticas y Culturales en el Proceso de Formación de la Ciudadanía en Colombia: 
1810-1860”, Anuario de Historia Regional y de las Fronteras, 16 (2011), pp. 295-316.

MARTÍ, José, La América, Nueva York, mayo de 1884, en Obras completas. Vol. III. La Habana, 1963.

MARTÍNEZ ALCUBILLAS, Marcelo, Diccionario de la administración española. Compilación de la novísima legislación de España en todos los ramos de administración pública, Madrid, 1923.

MARTÍNEZ, Frédéric, El nacionalismo cosmopolita. La referencia europea en la construcción nacional en Colombia, 1845-1900, Bogotá, Banco de la República, Instituto Francés de Estudios Andinos, 2001.

MORENO LUZÓN, Javier, "Entre el progreso y la Virgen del Pilar. La pugna por la memoria en el centenario de la Guerra de la Independencia”, Historia y Política, 12 (2004), pp.41-78.

MORRA, Nello, "Laicismo", Novissimo Digesto Italiano, Vol. IX, Torino, 1963.

NISBET, Robert, Historia de la Idea de Progreso, Ed. Gedisa, Barcelona, 1996.

OSSENBACH SAUTER, Gabriela, "Estado y educación en América latina a partir de su independencia” (siglos XIX-XX), Revista Iberoamericana de Educación, 1 (2013), pp. 95-115.

PAULINO, José, La secularización de la religión en el modernismo, 'Ilu, 3, (1998), pp. 209-221.

PEÑA, María Antonia and ZURITA, Rafael, "The peruvian native and the conception of liberal citizenship in the Latin American context”, en SIERRA, María, Enemies Within: Cultural Hierarchies and Liberal Political Models in the Hispanic World, Newcastle, Cambridge Scholars Publishing, 2015, pp. 7-40.

PI Y MARGALL, Francisco, La reacción y la revolución. Estudios políticos y sociales T.I, Madrid, Imp. de M. Rivadeneyra, 1854, p. 200. 
QUIJADA, Mónica, BERNAND, Carmen y SCHNEIDER, Arnd, Homogeneidad y nación con un estudio de caso: Argentina, siglos XIX y XX, Madrid, CSIC, Colección tierra nueva e cielo nuevo, 42, 2000.

ROBERT, Roberto, Los cachivaches de antaño, Madrid, 1869.

ROGADO, Jesús, “Historia, teleología y religión”, Relaciones Internacionales, 8 (2008), pp.1-16.

RUBIO, Carlos, Teoría del Progreso, folleto escrito en contestación al que con el título de "La fórmula del progreso" ha publicado D. Emilio Castelar por Carlos Rubio, Madrid, Imp. Manuel de Rojas, 1859.

SÁNCHEZ, Cecilia, Una disciplina de la distancia. Institucionalización universitaria de los estudios filosóficos en Chile, Santiago de Chile, 1992.

STUVEN, Ana María (ed.), La religión en la esfera pública chilena: ¿laicidad o secularización? Santiago Chile, Ed. Universidad Diego Portales, 2014.

SUÑER Y CAPDEVILA, Francisco, “La caída del papado”, Anuario Republicano Federal, Madrid, 1870, pp. 448-458.

TOURAINE, Alain, Crítica de la modernidad, Madrid, Temas de hoy, 1993.

WEBER, Max, La ética protestante y el espíritu del capitalismo, Edición original 1904/1905, Edición electrónica, 2009, www.laeditorialvirtual.com.ar

WEINBERG, Gregorio, "Ilustración y educación superior en Hispanoamérica” en Simposium Internacional sobre Educación $e$ Ilustración. Dos siglos de reformas en la enseñanza, Madrid, MEC, 1988, pp. 31-58. 